\title{
IMPLEMENTATION OF PROFESSIONAL ZAKAT BASED ON THE REGIONAL REGULATION OF PALEMBANG CITY NUMBER 4 OF 2017 AT THE PALEMBANG CITY GOVERNMENT OFFICE
}

\author{
M. Tamudin ${ }^{1}$, Yusida Fitriyati ${ }^{2}$
}

\begin{abstract}
This paper examines the implementation of professional zakat based on the regional regulation of the city of Palembang Number 4 of 2017 concerning zakat management at the Palembang city government office.This research is a field research by conducting a study of the laws that apply in society. This study looks at the application of professional zakat based on the Regional Regulation of Palembang City Number 4 of 2017 at the Palembang City Government Office. There are 3 problem formulations in this study, including "1. How is the implementation of professional zakat based on the Regional Regulation of Palembang City Number 4 of 2017 at the Palembang City Government Office? 2. What are the factors that influence the implementation of professional zakat based on the Regional Regulation of Palembang City Number 4 of 2017 at the Palembang City Government Office? 3. What are the efforts made by the Palembang City Government in overcoming the problem of implementing professional zakat based on the Palembang City Regional Regulation Number 4 of 2017? From the results of the study it can be concluded that the implementation of professional zakat based on the regional city regulation of Palembang number 4 of 2017 in the Palembang city government office has been carried out but has not been maximized. There are still many ASNS (civilApparatus) who have not deposited professional zakat to the Palembang City BAZNAS. His awareness of paying professional zakat has only reached 13\% of the existing muzakki. The enforcement of administrative sanctions or fines has also not been implemented due to political reasons. The factors that influence the implementation of professional zakat in the Palembang city government office are: the rule of law factor, the Palembang City BAZNAS factor,
\end{abstract}

Keywords :Implementation, regional regulations, professional zakat.

\section{The Introduction}

Zakat is a real form of social solidarity in Islam, because with zakat can grow a sense of togetherness and responsibility to help each other among the community members, while eliminating selfish and individualistic traits (Nurul Huda, 2015: 12). Indonesia, as one of the countries with a Muslim population of more than $90 \%$, has regulated the issue of zakat through Law Number 23 of 2011 concerning Management of Zakat.. This is intended as a form of state concern for the rights of the poor in Indonesia. Indonesian Constitution also has been equipped with Regulations Government Number 14 of 2014 concerning the Implementation of Law Number 23 of 2011 concerning Management of Zakat, as well as Presidential Instruction Number 3 of 2014 concerning the obligation of civil servants to pay zakat to Baznas.

1 Fakultas Syariah dan Hukum UIN Raden Fatah Palembang, Email: m.tamudin_uin@radenfatah.ac.id

2 Fakultas Syariah dan Hukum UIN Raden Fatah Palembang, Email: yusidafitriyati_uin@radenfatah.ac.id 
Amin Suma stated that how important it is that zakat regulations can actually regulate, bind and even "force" in the management of zakat funds.professionally, procedurally and proportionally (Amin Suma, 2019: 252). State intervention, especially the government, is expected to be able to manage zakat funds better and correct. The management of Zakat funds by the state (government) is in accordance with the 1945 Constitution Articles 33 and 34 .

The regional government of Palembang with the approval of the Palembang City, People's Representative Council has enacted Regulations Area Palembang City Number 4 of 2017 concerning Zakat Management which has been in effectively in the jurisdiction of the city of Palembang since February 22, 2017. In the regional regulation it is emphasized that one of the subjects of zakat is the State Civil Apparatus who is to distribute zakat income through the Palembang City BAZNAS . And if they do not carry out the distribution of zakat to BAZNAS Palembang City, they will be subject to administrative sanctions or fines.

This study analyzes the implementation of professional zakat for State Civil Apparatus based on the provisions of the Palembang City Regional RegulationNumber 4 of 2017. This aims to collect professional zakat funds from the State Civil Apparatus who set aside a small portion of their income to be donated to parties in need in accordance with the provisions of applicable Islamic law and can encourage broad economic growth, especially economic growth in Indonesia. Palembang city in an effort to improve the welfare of the people of Palembang city.

\section{Research methods}

This research is a field research that is looking at the application of professional zakat in the Palembang City Government Office. based on the Regional Regulation of Palembang City Number 4 of 2017. The approach used in this study is an empirical juridical approach. The author chooses this type of approach more because it is more flexible and allows for innovations in the field. The choice of this method is because it is in accordance with the focus of the problem that wants to reveal the application of professional zakat in the Palembang City Government Office based on the Palembang City Regulation Number 4 of 2017. The population of this research is all units related to the application of professional zakat at the Palembang City Government office. The sampling technique used purposive sampling method, namely the determination of samples taken based on certain characteristics and characteristics. The data needed in this research is qualitative data. The qualitative data includes the rules, the mechanics of applying Professional Zakat, the management of professional zakat, the role of the Palembang City BAZNAS Institution.

There are 2 sources of data in this study, namely: 1 . Primary data is data obtained directly from the field by conducting in-depth interviews with respondents. The social facts are empirical-descriptive. 2. Secondary data includes: a. Primary legal materials consist of statutory regulations concerning Zakat Management. b. Secondary legal materials include: research results, scientific writings, literature books, journals and materials from the internet that are related to research problems. c. The collection of normative-prescriptive legal materials is carried out by tracing, collecting and 
studying documents both conventionally and using information technology. While the collection of empirical-descriptive social facts is carried out using in-depth interviews with respondents. The data that has been collected was analyzed descriptively qualitatively, namely describing, presenting and describing all the existing problems clearly. Then it is concluded deductively, namely drawing conclusions from statements that are general in nature and drawn to specific statements.

\section{Discussion and Results}

\section{Zakat Setting Profession in Palembang City.}

The implementation of zakat management at the regional level is regulated through regional regulations. In the city of Palembang, zakat management is regulated through Article 2 of the RegulationAreaPalembang City Number 4 of 2017. Based on the Regional Regulation, the implementation of zakat management must be based on the following principles: a. Islamic law; b. trusts; c. benefits; d. Justice; e. legal certainty; f. integrated; and, g. accountability

The objectives of zakat management are:

a. improve the effectiveness and efficiency of services in the management of zakat;

b. increase the benefits of zakat to realize community welfare and poverty alleviation;

c. improve services for the community and pay zakat in accordance with the provisions of the Islamic religion.

The subjects of zakat based on Article 4 Paragraph (1) of Regional Regulation Number 4 of 2017 are:

a. every capable Muslim state civil apparatus;

b. capable employees of regional-owned enterprises who are Muslim;

c. a Muslim-owned business entity domiciled in the City;

d. every Muslim who can afford it.

Meanwhile, the object of zakat is zakat maal and zakat fitrah. Zakatmaal consists of: gold, silver and other precious metals; money and other securities; commerce; agriculture, plantation and forestry; livestock and fisheries; mining; industry; income/profession and services; and rikaz; present.

Zakat profession is one of the objects of zakat maal, which can be applied to capable Muslim state civil servants, capable Muslim employees of regional owned bodies and Muslim-owned enterprises domiciled in the city of Palembang..

In order to collect zakat, Muzakki can do their own calculation of their zakat obligations. If Muzakki cannot calculate his zakat obligation him self, then Muzakki can ask BAZNAS for help Palembang city. For Civil Servants and employees of Regional Owned Enterprises in the City Government area Palembang must distribute zakat to BAZNAS Palembang City. As for StateOwned Enterprisesand private companies within the Palembang City area are encouraged to distribute their zakat to the Palembang City BAZNAS. Especially for professional zakat for state civil servants and other government administrations, employees of State-Owned Enterprises I Regional-Owned Enterprises, and employees of private companies are collected by zakat collectors as Unit Collector Zakat (special unit for collecting 
Zakat) spec and then deposited into the Palembang City BAZNAS account at Bank Sumsel Babel Palembang Zakat Account Number150.09.32911. appointed or channeled directly to the Palembang City BAZNAS.

In Article 22 PerPalembang City Regional Regulations Number 4 of 2017 concerning the management of zakat, it is stated that "Zakat" paid by Muzakki to BAZNAS The city can be deducted from taxable income" by showing proof of deposit zakat for muzakki issued by BAZNAS Palembang City.

Palembang City Regulations Number 4 of 2017 also regulates the existence of administrative sanctions for State Civil Apparatus or Regional Owned Enterprises who do not distribute their zakat to BAZNAS Palembang city. This is stated in Article 21 paragraph (3) of the Regional Regulation of Palembang City Number 4 of 2017 which reads "Civil Servants" and employees of Regional Owned Enterprises in the City Government area Palembang is obliged to distribute zakat to BAZNAS Palembang City. These provisions are mandatory. administrative sanctionsin the form of a fine of $\mathrm{Rp}$. $25,000,000$,- (twenty five million rupiah) or replaced with imprisonment for 4 (four) months, preceded by a written warning from the City BAZNAS and then a written warning from the Mayor. If examined carefully, Article 21 paragraph (3) of Regional Regulation a Palembang City Number 4 of 2017 is a manifestation of the legal rules of professional zakat for Civil Servants and Employees of Regional-Owned Enterprises in the city of Palembang which are imperative. And the administrative sanctions are a form of punishment given by the government so that the State Civil Apparatus realizes that paying zakat is an obligation that must be carried out by capable Muslims and the state is to intervene in this matter.

\section{Implementation of Zakat Profession Based on Regulation Area Palembang city Number 4 of 2017.}

ZakatProfession is a new term that is developing in contemporary fiqh studies, which was popularized by Yusuf Qardhawi in the Book of Fiqh alZakah by using the word kasb al-"amal wa al-mihn al-hurrah which is defined as a search and a profession, namely every business that produces wealthy. in the form of money and so on, whether carried out using physical abilities, hand skills or brain abilities, including the services and efforts of individuals or groups (Yusuf Qardhawi, 1969: 487). Also included in professional zakat are professions or income earned through their expertise, whether they are done independently, such as doctors, architects, lawyers, painters, preachers and others.

The implementation of professional zakat in Indonesia has been responded to by several regions, one of which is Palembang City. The Mayor of Palembang has issued a Decree of the Mayor of Palembang Number 276/KPTS/II/2017 regarding Zakat Income, Infaq and Sadaqah for State Civil Apparatus and Employees of Regional Owned Enterprises in the City Government EnvironmentPalembang and Private Employees. The decision of the Mayor of Palembang is a derivative of the Regulation of the Mayor of Palembang area of Palembang City Number 4 of 2017 concerning Management of Zakat Jo. Law Number 23 of 2011 concerning Management of Zakat and Government Regulation Number 14 of 2014 concerning Implementation of Law Number 23 of 2011 concerning Management of Zakat. 
The Implementation of professional zakat in the government of Palembang City This is done by forming a Zakat Collecting Unit(UPZ) at the Palembang City Government Office, as an effort to facilitate the collection of professional zakat in each unit in the Palembang City Government Office. The Zakat Collecting Units in the Palembang City Government Office are 54 units, namely: Regional Secretariat, DPRD Secretariat, Tourism Office, Health Service, Manpower Office, Social Service, Transportation Service, Education Office, Investment and One Stop Service Office, Controlling Service. Population and Family Planning, Department of Population and Civil Registration, Department of Public Works and Spatial Planning, Department of Agriculture and Food Security, Department of Cooperatives and Small and Medium Enterprises, Department of Culture, Department of Youth and Sports, Department of Fisheries, Department of Environment and Hygiene, BARI, KPU Secretariat, Fire Service and Disaster Management, Communication and Information Service, Archives and Library Service, Women's Empowerment Service, Child Protection and Community Empowerment, PNS Teachers, Seberang Ulu 1 District, Sukarami District, Sako District, Alang-alang District Lebar , Kemuning District, Sematang Borang District, Jakabaring District, IlirTimur District 3.

The subject of professional zakat in the Palembang City Government Officeis every capable Muslim state civil apparatus. Zakat profession penalized for Muzakki in the Palembang City Government Office with income that has reached the nishab of $2.5 \%$ of the salary/gross income of the State Civil Apparatusin agencies/work units with a nishab of 85 (eighty five) grams of gold, equal to Rp. 40,800,000, - (forty million eight hundred thousand rupiah) per year or Rp. 3,400,000, - (three million four hundred thousand rupiah) per month. Based on data from BAZNAS Palembang city regarding the number of muzakki in the Palembang City government in 2018 and 2019 are as follows:

Table 1

Number of Muzakki in the Palembang City Government Office Environment 2018 and 2019

\begin{tabular}{|c|c|c|c|c|}
\hline \multirow[t]{2}{*}{ No. } & \multirow[t]{2}{*}{ work units } & \multicolumn{2}{|c|}{ year } & \multirow{2}{*}{ Total } \\
\hline & & 2018 & 2019 & \\
\hline 1. & Regional Secretariat & 140 & 184 & 324 \\
\hline 2. & DPRD Secretariat & 40 & 51 & 91 \\
\hline 3. & Government tourism office & 42 & 56 & 98 \\
\hline 4. & public health office & 1016 & 1446 & 2462 \\
\hline 5. & employment agencies & 47 & 54 & 101 \\
\hline 6. & social services & 48 & 49 & 97 \\
\hline 7. & $\begin{array}{l}\text { Department } \\
\text { Transportation }\end{array}$ & 102 & 157 & 259 \\
\hline 8. & $\begin{array}{l}\text { Education Office * } \\
\text { Teachers })\end{array}$ & 597 & 6983 & 7580 \\
\hline 9. & $\begin{array}{lr}\text { One-Stop } & \text { Integrated } \\
\text { Service and Investment } \\
\text { Service }\end{array}$ & 53 & 82 & 135 \\
\hline 10. & $\begin{array}{l}\text { Office of Population Control } \\
\text { and Family Planning }\end{array}$ & 104 & 69 & 173 \\
\hline 11. & $\begin{array}{l}\text { Department of Population } \\
\text { and Civil Registration }\end{array}$ & 32 & 68 & 100 \\
\hline 12. & Department & 133 & 166 & 299 \\
\hline
\end{tabular}




\begin{tabular}{|c|c|c|c|c|}
\hline \multirow[t]{2}{*}{ No. } & \multirow[t]{2}{*}{ work units } & \multicolumn{2}{|c|}{ year } & \multirow[t]{3}{*}{ Total } \\
\hline & & 2018 & 2019 & \\
\hline & $\begin{array}{lll}\text { Works } & \text { and } & \text { Spatial } \\
\text { Planning } & & \\
\end{array}$ & & & \\
\hline 13. & $\begin{array}{l}\text { Department of Agriculture } \\
\text { and Food Security }\end{array}$ & 86 & 98 & 184 \\
\hline 14. & $\begin{array}{l}\text { Office of Cooperatives and } \\
\text { Small and Medium } \\
\text { Enterprises }\end{array}$ & 34 & 41 & 75 \\
\hline 15. & Culture Service & 35 & 50 & 85 \\
\hline 16. & Youth and Sports Office & 45 & 51 & 96 \\
\hline 17. & Fisheries Service & 33 & 36 & 69 \\
\hline 18. & $\begin{array}{l}\text { Department of } \\
\text { Environment and Hygiene }\end{array}$ & 70 & 106 & 176 \\
\hline 19. & $\begin{array}{l}\text { Department of Public } \\
\text { Housing and Residential } \\
\text { Areas }\end{array}$ & 62 & 81 & 143 \\
\hline 20. & Department of Commerce & 37 & 45 & 82 \\
\hline 21. & Department of Industry & 38 & 42 & 80 \\
\hline 22. & $\begin{array}{l}\text { Regional Tax Management } \\
\text { Agency }\end{array}$ & 156 & 219 & 375 \\
\hline 23. & $\begin{array}{l}\text { Agency for Personnel and } \\
\text { Human } \\
\text { Development }\end{array}$ & 48 & 68 & 116 \\
\hline 24. & $\begin{array}{l}\text { Regional Development } \\
\text { Planning Agency, Research } \\
\text { and Development }\end{array}$ & 48 & 57 & 105 \\
\hline 25. & $\begin{array}{l}\text { Regional Financial } \\
\text { Management Agency and } \\
\text { Regional Assets }\end{array}$ & 67 & 84 & 151 \\
\hline 26. & $\begin{array}{l}\text { National and Political } \\
\text { Unity Agency }\end{array}$ & 21 & 33 & 54 \\
\hline 27. & Narcotics Agency & 9 & 8 & 17 \\
\hline 28. & City Inspectorate & 58 & 60 & 118 \\
\hline 29. & Civil Service Unit & 101 & 180 & 281 \\
\hline 30. & Palembang Hospital BARI & 226 & 335 & 561 \\
\hline 31. & Opposite Ulu I . District & 31 & 38 & 69 \\
\hline 32. & Sukarami District & 56 & 75 & 131 \\
\hline 33. & Sako District District & 52 & 58 & 110 \\
\hline 34. & Reeds Lebar District & 47 & 51 & 98 \\
\hline 35. & Kemuning District & 50 & 56 & 106 \\
\hline 36. & Sematang Form District & 30 & 43 & 73 \\
\hline 37. & Jakabaring District & 37 & 45 & 82 \\
\hline 38. & IlirTimur District 3 & 40 & 55 & 95 \\
\hline 39. & KPU Secretariat & 1 & 1 & 2 \\
\hline 40. & $\begin{array}{l}\text { Fire Service and Disaster } \\
\text { Management }\end{array}$ & 111 & 241 & 352 \\
\hline 41. & $\begin{array}{ll}\text { Department } & \text { of } \\
\text { Communication } & \& \\
\text { Information } & \\
\end{array}$ & 35 & 49 & 84 \\
\hline 42. & $\begin{array}{l}\text { Office of Archives and } \\
\text { Libraries }\end{array}$ & 44 & 45 & 89 \\
\hline 43. & $\begin{array}{lr}\text { Office of } & \text { Women's } \\
\text { Empowerment, } & \text { Child }\end{array}$ & 31 & 36 & 67 \\
\hline
\end{tabular}




\begin{tabular}{|l|l|c|c|c|}
\hline \multirow{2}{*}{ No. } & \multicolumn{1}{|c|}{ work units } & \multicolumn{2}{|c|}{ year } & Total \\
\cline { 3 - 4 } & & $\mathbf{2 0 1 8}$ & $\mathbf{2 0 1 9}$ & \\
\hline & $\begin{array}{l}\text { Protection and Community } \\
\text { Empowerment }\end{array}$ & & & \\
\hline 44. & Civil Servant Teacher & 6641 & - & 6641 \\
\hline 45. & Ilir Barat District I & 59 & 63 & 122 \\
\hline 46. & $\begin{array}{l}\text { Ilir Barat II District } \\
\text { District }\end{array}$ & 56 & 52 & 108 \\
\hline 47. & Opposite Ulu II District & 55 & 54 & 109 \\
\hline 48. & Plaju District District & 58 & 58 & 116 \\
\hline 49. & IlirTimur District I & 69 & 71 & 140 \\
\hline 50. & IlirTimur District II & 50 & 55 & 105 \\
\hline 51. & Kertapati District & 53 & 53 & 106 \\
\hline 52. & Kalidoni District District & 44 & 55 & 99 \\
\hline 53. & Little Hill District & 53 & 49 & 102 \\
\hline 54. & Gandus District District & 39 & 45 & 84 \\
\hline & Total & $\mathbf{1 1 . 2 7 0}$ & $\mathbf{1 2 , 2 5 2}$ & $\mathbf{2 3 , 5 2 0}$ \\
\hline
\end{tabular}

Source: BAZNAS Office Data Palembang city, August 2020.

Based on Table 1 above, can be explained that the number of Muzakki in the Palembang City Government Office in 2018 there were 11,270 people, and in 2019 there were 12,252 people. There was an increase in the number of Muzakki in the Palembang City Government Office as much as $8.71 \%$ in the period $2018-2019$.

Provisions of Article 22 of the Regulations Area Palembang city Number 4 of 2017 which confirms that "Zakat" paid by Muzak kito BAZNAS Kota is deducted from taxable income". In fact, the provisions of Article 22 of the Regional Regulation of the City of Palembang Number 4 of 2017 have not been realized. This has been discussed at the National BAZNAS Working Meeting, but because there is no SOP (procedure) in the Ministry of Finance regarding tax deductions due to paying professional zakat, this provision cannot be realized in Palembang City. (R1, BAZNAS Palembang City).

However, BAZNAS Palembang city has made an estimate of professional zakat for 1 year, in this case 2018 and 2019, so that the Palembang City BAZNAS have an overview of the potential for professional zakat funds from the State Civil Apparatusin the Palembang City Government Office. In addition, the estimation of professional zakat within the Palembang City Government Office is a target that must be achieved by the Palembang City BAZNAS as a zakat management institution, including professional zakat. The higher the achievement target of obtaining professional zakat in the city of Palembang, the better for improving the economic quality of Muslims in the city of Palembang. Estimated Zakatfor 1 year will be cross-checked with the realization of professional zakat receipts at BAZNAS Palembang City. The estimation of professional zakat for 1 year and the realization of professional zakat receipts in 2018 and 2019 can be explained in Table 2 below 
Table 2

Estimated and Realized Zakat Receipt Profession BAZNAS Palembang city 2018 and 2019

\begin{tabular}{|l|c|c|c|c|c|c|}
\hline No. & \multicolumn{3}{|c|}{2018} & \multicolumn{2}{c|}{2019} \\
\cline { 2 - 7 } & $\begin{array}{c}\text { Total } \\
\text { Muzakki }\end{array}$ & $\begin{array}{c}\text { Estimated Zakat } \\
\text { 1 year } \\
(\mathrm{Rp})\end{array}$ & $\begin{array}{c}\text { Realizatio } \\
\text { n of Zakat } \\
\text { Receipt }\end{array}$ & $\begin{array}{c}\text { Total } \\
\text { Muzakki }\end{array}$ & $\begin{array}{c}\text { Estimated Zakat } \\
\text { 1 year } \\
(\mathrm{Rp})\end{array}$ & $\begin{array}{c}\text { Realization } \\
\text { of Zakat } \\
\text { Receipt }\end{array}$ \\
\hline 1. & 11.270 & $11,478,570,000$ & $13.67 \%$ & 12,252 & $12,385,350,000$ & $13.43 \%$ \\
\hline
\end{tabular}

Source: BAZNAS Office Data Palembang city after processing, August 2020.

Based on Table 2 above, the estimated professional zakat in 2018 is targeted at Rp. 11,478,570,000, - from 11,270 muzakki in the Palembang City Government Office. However, the realization of revenue only reached $13.67 \%$ (Rp. 1,569,069.526,-). And in 2019, the estimated professional zakat is targeted at Rp. 12,385,350,000, - from 12,252 muzakki in the Palembang City Government Office. Realization of professional zakat receipts in 2019 only reached $13.43 \%$ (Rp. 1,663,205,238, -). Thus, the realization of professional zakat receipts in 2018 and 2019 in the Palembang City Government Office is still very low and has not reached the target that has been set either by BAZNAS Palembang city or the Mayor's expectation for the implementation of the Regulations Major Number 276/KPTS/II/2017 and Regional Regulations Number 4 of 2017.

From Table 2 it can also be understood that there are still approximately $86 \%$ muzakki from several work units in the Palembang City government office who have not deposited professional zakat to the Palembang City BAZNAS. Referring to the provisions of the Palembang City Regional Regulation Number 4 of 2017 and clarified again in the provisions of the Palembang Mayor's Decree Number 276/KPTS/II/2017 that "For State Civil Apparatuses", Employees of Regional Owned Enterprises within the city governmentPalembangand Private Employees who do not distribute their zakat are subject to administrative sanctions in the form of a fine of $\mathrm{Rp}$. 25,000,000,- (twenty five million rupiah) or replaced with imprisonment for 4 (four) months in accordance with the provisions of Article 33 of the Regulation Area Palembang City Number 4 of 2017, with the following provisions:

a. If the person concerned does not distribute his zakat for 3 (three) months, then the next 15 (fifteen) days, a written Warning Letter I will be issued from the Amil Zakat Agency.City National, and if the following 15 (fifteen) days there is no clarification from the person concerned, a written Warning Letter II from the Mayor will be issued; and

b. If within 15 (fifteen) days from Warning Letter II there is no clarification, the Amil Zakat Agency The City National will report the person concerned to the competent authority in accordance with the provisions of the applicable laws and regulations.

Law enforcement in the form of administrative sanctions or fines for State Civil Apparatus within the Palembang City government that does not distribute professional zakat to Palembang City BAZNAS has not been realized. This is due to political considerations. However, social and psychological sanctions have been carried out by the Regional Secretary of 
Palembang City by announcing work units within the Palembang City Government that have not paid professional zakat to the Palembang City BAZNAS.at the meeting or activity attended by the Head of Service or the Head of the Work Unit based on the data that has been reported by the Head of City BAZNAS to the Mayor. So that every Head of Service or Head of Work Unit whose employees have not paid professional zakat to BAZNAS Palembang City feels ashamed and can order all State Civil Apparatus in their respective work environments to carry out and pay professional zakat to BAZNAS Palembang City. Social sanctions and psychological activities carried out by the Regional Secretary of Palembang City are quite effective in increasing the number of Muzakkipay professional zakat to BAZNAS Palembang. This can be seen from the increase in the number of muzakki in 2018 as many as 11,270 muzakki to 12,252 muzakki (8.71\%).

Thus it can be concluded that the implementation of professional zakat based on Area Palembang cityNumber 4 of 2017 in the Palembang City Government Office has been running, although it has not achieved encouraging results. There is still a low level of awareness among State Civil Apparatus in the Palembang City Government Office that professional zakat is something that must be carried out based on the provisions contained in Regional Regulation Number 4 of 2017. Administrative sanctions and fines also cannot be applied to ASN in the City Government Office environment Palembang who have not paid professional zakat to BAZNASPlembang City.

Factors that influence the implementation of professional zakat based on regulations Area Palembang city Number 4 of 2017.

The formalization of Islamic law regarding services and professions as assets subject to zakat maal, referred to as zakat income and services or professional zakat, which has been stated in Article 4 Paragraph (2) letter $\mathrm{h}$ of Law Number 23 of 2011 concerning zakat management. And in the city of Palembang, the regulation of professional zakat issues is contained in the RegulationsAreaPalembang City Number 4 of 2017 concerning the management of zakat. Even though there are laws and regional regulations that regulate the management of zakat, they do not automatically apply. Many factors influence so that a rule of law can be implemented properly.

Friedman explained that the factors that influence the enforcement of a rule include legal substance, legal structure and legal culture. The legal structure is an institution created by a legal system. The legal substance is in the form of substantive legal regulations and legal regulations on how institutions should be (created by substantive legal regulations). And legal culture, which is in the form of habits, views, ways of behaving and thinking, which moves people to obey or disobey the law (Friedman, 1997).

The same thing was also stated by Soerjono Soekanto that "law enforcement is a process" (Soerjono Soekanto, 1983: 4). The process of implementing the rule of law is influenced by several factors, namely: a. The legal factor; b. factor of law enforcement officers; c. facilities and infrastructure factors; $d$. community factors; e. cultural factors. 


\section{a. Legal Regulation.}

Laws or statutory regulations in a more tangible spectrum are placed as the rules of the game in the implementation of state, government and social processes, which aim as "opgelegd on the summenleving vreedzaam, rechtvardig, en dolmatig te ordenen" (Algra, 1974: 10)). The law was put in place to organize society to regulate society so that peace, justice and life are more meaningful.

The implementation of government and state duties in a legal state refers to the legal rules written in the constitution or the regulations compiled in constitutional law. However, in the implementation of constitutional law, it is not sufficient to cover all areas of government, therefore Constitutional Law requires another law of a technical nature called state administrative law. It is the state administrative law that applies as an extension of constitutional law in regulating technical matters (Ridwan, 2002: 18).

Indonesia is a state of law. The rule of law is defined by FR Bothlingk, as "de staat waarin de wilsvrijheid van gezagsdragers is beperkt door grenzen van recht" (a state of law is a state that limits the freedom of the will of power holders with legal provisions (Ridwan, 2002; 16).The rule of law is to limit movement.This has been regulated hierarchically in the Law as follows:

1. Constitution of the Republic of Indonesia 1945

2. MPR Decreet

3. Laws or Regulations Government in Lieu of Law

4. Government Regulation / PP

5. President Regulation

6. District and provens (Area) Regulation.

Indonesia as a country that was formerly a Dutch colony until now still has the characteristics of the Dutch legal system which tends to be continental. According to the continental legal system, the legal regulations are divided into 3 (three) groups (Riant Nugroho, 2013: 10). The three groups are:

1. Regulationmacro or basic legislation. Usually regulations of this type include: the 1945 Constitution, TAP MPR, UU/PERPU.

2. Regulationwhich is messo, or intermediate or explanatory of implementation. Usually regulations of this type are classified as Government Regulations and Presidential Regulations.

3. RegulationMicro legislation is a policy that regulates the implementation or implementation of the regulations above it. This type of regulation includes regional regulations.

Ideally Rules Area Palembang cityis explained again by the Palembang Mayor's Regulation as a regulation that is regulating (regeling) not explained by a decree. because the Decree does not have the status of an explanation for the Mayor's Regulation but conveys the validity of the Regulation not as an explanation but as a decision that is (beschikking). Beschikking, defined as government decisions for concrete and individual matters, is not intended for general matters (Ridwan, 2002: 10).

There are several reasons why this PERDA has not been followed up with a Mayor Regulation, including: 1 . There are concerns among the 
Palembang City government Regulation This will give a heavier burden to the employees in the City Government environmentPalembang in terms of issuing monthly contributions because apart from their professional zakat, they have previously been charged with paying other contributions in the form of income tax, which was strengthened by the issuance of a Regulation of the Minister of Finance. 2. There is a political concern among the officials of the Palembang City Government that if the withdrawal of professional zakat is enforced, it will reduce support for the government led by the current major.

\section{b. Amil Zakat Agency in Palembang City.}

Amil Zakat AgencyNational is an institution authorized to carry out the task of managing zakat nationally. Zakat management is an activity of planning, planning, and coordinating in the collection, distribution and utilization of zakat. To manage zakat at the provincial and city/district levels, BAZNAS was formed Province and BAZNAS City/district.

BAZNAS Palembang city is one of the existing City/Regency BAZNAS and is responsible to the BAZNAS of South Sumatra Province and the Mayor of Palembang. The Palembang City BAZNAS office occupies one of the rooms in the City Government Office BuildingPalembang. The existence of the Palembang City BAZNAS Office is very small and narrow, so it is less representative to provide services to Muzakki or Zakat Management Unit(UPZ) which will pay zakat. This condition can also affect the implementation of zakat payments (professional zakat). Supposedly, the Palembang City BAZNAS Office occupies a special building so that Palembang City BAZNAS can provide better services to all Muzakki and mustahik.

BAZNAS organizational structure Palembang city was formed as a mandate contained in Article 41 of the Regulations Government Number 14 of 2014 concerning the Implementation of Law Number 23 of 2011 concerning Management of Zakat, which explains that Regency/City BAZNAS consists of elements of leadership and implementers. The leadership in question consists of the chairman and at least 4 (four) deputy chairmen. The organizational structure of BAZNAS Palembang Cityconsists of 1 chairman, namely Drs. HM SaimMarhadan, and 3 deputy chairmen consisting of Deputy Chair I: Drs. MaruziTarmizi; Deputy Chair II : EmanSatriaHady, S.IP., M.Si; and Deputy Chair III : Drs. Tarmizi, MM. When this research was conducted, it turned out that there were only 2 active BAZNAS leaders in Palembang City, namely Drs. HM SaimMarhadan and Mr. Drs. MaruziTarmizi. While the other 2 people, 1 (one) person died and 1 (one) person resigned. So far, there has been no replacement. The duties of Deputy Chair II for the distribution and utilization of zakat, as well as the duties of Deputy Chair III for finance, reporting, HR and general affairs were delegated to Drs. MaruziTarmizi as Deputy Chair I who has been in charge of zakat collection only. This causes the duties and responsibilities of vice chairman I to increase, pile up and be ineffective because they have to do all the tasks that should be done by other vice chairman. This condition should be the concern of the Chairman of BAZNAS of Palembang City and the Mayor of Palembang to add personnel to the ranks of the vice chairman. This shortage of 
personnel also affects performance, spirit and dedication in order to work optimally and professionally.

The human resource factor plays a very important role in managing zakat (professional zakat). In this case, adequate personnel are needed, have the ability to think or act creatively and innovatively. Knowledge, education, skills and experience are closely related to professionalism. Professionalism is the ability to plan, coordinate and carry out its functions efficiently, innovatively, flexible and has a high work ethic. Anshori also emphasized that professionalism is needed as an ability to carry out tasks so that it is achieved with high quality, right time, carefully with procedures that are easy to understand and follow by the community (Abdul Ghafur Anshori, 2006: 133). Professional zakat management requires skilled,

c. ASN Awareness in the City Government Office environment Palembang.

The potential for professional zakat originating from the state civil apparatus (ASN) provides a great opportunity for the collection of zakat funds through BAZNAS. Potential professional zakat from the state civil apparatus (ASN) in the Palembang city government officecan reach $\mathrm{Rp}$. 18,000,000,000, - (Eighteen billion) per year from 15,000 state civil apparatus or ASN in the Palembang city government. This was stated by the Regional Secretary (Sekda) of the city of Palembang who explained that the potential for zakat was calculated with the assumption that the zakat issued by tens of thousands of ASN was around Rp. 100,000, - (one hundred thousand) per month. If one month can reach Rp. 1,500,000,000, (one billion five hundred million rupiah). So in one year zakat funds can be collected in the amount of Rp. 18,000,000,000, - (Eighteen billion rupiah).

However, the realization of professional zakat payments in the City Government office Palembang has not reached the estimate that has been targeted by BAZNAS Palembang city. In 2018, the Palembang City BAZNAS set an estimated professional zakat payment of Rp. $11,478,570,000$, - and the realization only reached Rp. 1,569,069,526,(13,67\%). And in 2019 the estimated professional zakat is targeted at Rp. 12,385,350,000, - and realized Rp. 1,663,205,238,- (13,43\%). Thus, during 2018 and 2019, the realization of professional zakat receipts was approximately $13 \%$ of the estimate set by the Palembang City BAZNAS.

In 2018 there were 54 work units within the Palembang City Government Office, only 24 work units with more than 50\% ASN pay professional zakat to the BAZNAS office Palembang city. In fact, there are 16 work units whose ASN have not paid professional zakat at all through the Palembang City BAZNAS. And in 2019 there were 53 work units within the Palembang City Government Office, only 22 work units whose ASN more than 50\% paid professional zakat to the Palembang City BAZNAS Office. In fact, there are 17 work units whose ASN have not paid professional zakat at all through the Palembang City BAZNAS.

The low understanding of professional zakat also affects paying professional zakat through BAZNAS Palembang city. Zakat profession is understood only as a basic salary received by ASN, so that the deduction for professional zakat is only the basic salary. While what is meant by professional zakat is all gross salaries received by ASN including salary 
allowances for positions, performance allowances (TUKIN) or remuneration if a remuneration system has been implemented.

In addition, there is still an understanding of ASNthat the giving of zakat is more afdhal if it has reached the nishab and is given directly to the mustahik they want. There is a certain satisfaction if the zakat is delivered directly to the mustahik, and it can also strengthen the relationship between brothers and sisters if the zakat is given to the closest relatives.

\section{d. Facilities and infrastructure.}

Facilities and infrastructure or facilities are one of the factors that affect the implementation of a rule of law. Facilities or facilities include physical facilities, buildings, operational equipment, services and finance. Limited facilities or facilities can cause the implementation of the legal rules that have been set to be less effective.

BAZNAS Palembang citydoes not yet have its own representative building. Palembang City BAZNAS Office located inside the City Government Office BuildingPalembang. There are 2 rooms, 1 small room for the leadership room and 1 large room for staff or implementers. The leadership room is combined between the chairman's room and the other 3 vice-chairs. There is no barrier for privacy between the Chair and the other 3 vice chairmen and the condition of the room is also very cramped. Service for guests in the leadership room is also very limited. Likewise the condition of the room for staff or implementers. There are 13 staff or implementers who assist the duties of the Chair and deputy chairman at the Palembang City BAZNAS office and the rooms are also less representative.

The existing facilities in the staff or executor's workspace include computers, printers, tables, chairs, cupboards are good enough to support work in the BAZNAS Office Palembang city. However, because the condition of the room is very narrow, it seems less well organized. Facilities and infrastructure should be something that contributes to smooth work at BAZNAS Palembang City. Facilities and infrastructure have a very important role in enforcing a rule of law. Without a good facility, it is impossible for law enforcers to harmonize their supposed roles with their actual roles.

Condition of facilities and infrastructure at the BAZNAS Kantor Office Palembang city Of course it should be the attention of the Mayor of Palembang in order to be able to plan and prepare a representative BAZNAS Palembang City Office Building so that the Palembang City BAZNAS office can provide excellent and professional service for all muzakki and mustahik who need zakat services (professional zakat) in the future.

Representative building support and complete facilities at the BAZNAS office Palembang city and also supported by professional human resources shows that the Palembang city government is serious about implementing the zakat management law and Palembang city regulations regarding zakat management in the city of Palembang properly. 


\section{e. legal culture Public}

legal cultureis a habit, a way of looking, a way of acting and thinking in a general society that is able to influence social forces according to a certain direction of development. Differences in people's views on a rule of law will result in the effectiveness of the implementation of the rule of law being different between certain community groups and other community groups.

Payment of zakat maal (including professional zakat) is carried out by some ASN in the Palembang City Government Officeduring the fasting month or before Eid al-Fitr. Maal zakat funds (including professional zakat) will be distributed to poor relatives or people who are directly included in the zakat mustahik. The distribution of zakat funds like that has become a habit for some people who can afford it with the hope that people who can't afford it or mustahik zakat can also feel happiness during Eid al-Fitr.

The tendencies and habits of the community will certainly affect the implementation of professional zakat for ASN in the Palembang City Government Office to pay professional zakat to BAZNAS Palembang city.

\section{Conclusion}

Based on the description above, it can be concluded that the implementation of professional zakat based on the Palembang City Regional Regulation Number 4 of 2017 at the Palembang City government office has been carried out but has not reached the maximum target as estimated by the Palembang City BAZNAS. Law enforcement in the form of administrative sanctions or fines for muzakki in the Palembang City government office has not been enforced for political reasons. However, the Palembang city government implemented social sanctions to overcome these problems. The factors that influence the implementation of professional zakat based on the Regional Regulation of the City of Palembang Number 4 of 2017 at the Palembang City government office are Regulations of the City of Palembanglaws; b. BAZNAS Palembang city; c. ASN Awareness in the City Government Office environmentPalembang; d. Facilities and infrastructure; e. legal culture public. 


\section{References}

Abdul Ghafur Anshori. (2006). Zakat Law and Empowerment Mandatory Synergy Effort Zakat and Taxes in Indonesia, Yogyakarta, Pilar Media.

Abu Ubayd Ibn Salam. (1987). Al-Amwal, Bairut, Dar al-Kutub al-Silmiah.

Muhammad Amin Suma. (2019). Synergy of Jurisprudence and Zakat Law, Jakarta, Kholam Publishing.

NE Algra en HCJG Jansen, Rechtsing, Een Oroentasi in Het Recht, HD Tjeenk Willinkbv, Groningen, 1972.

Nurul Huda, et.all., (2015). Zakat Micro-Macro Perspective (Research Approach), Prenada Media Group, Jakarta.

Rian Nogrorho. (2013). Policy Research Methods, Student Library, Yogyakarta.

Ridwan HR. (2002). State Administrative Law, Yogyakarta, UII Press.

Soerjono Soekanto. (1983). Factors Affecting Law Enforcement, Jakarta, Rajawali.

W. Friedman. (1997). The State And The Rule of Law In a mixed economy, Stevens \& Sons : London.

Yusuf Qardhawi, (1969). Fiqh al Zakah, Bairut, Muassasah Minutes.

Law Number 12 of 2011 concerning the Establishment of Regulations Legislation.

Constitution Republic of Indonesia Number 23 of 2011 concerning Management of Zakat.

Regulation Government of the Republic of Indonesia Number 14 of 2014 concerning the Implementation of Laws Republic of Indonesia Number 23 of 2011 concerning Management of Zakat.

Regulation Area Palembang city Number 4 of 2017 concerning Zakat Management.

Palembang Mayor's Decision Number 276/KPTS/II/2017 concerning Zakat Income, Infaq and Sadaqah for State Civil Apparatus and Employees of Regional Owned Enterprises within the city government Palembang and Private Employees. 
(2) 